\title{
A cultura castreja (c. III a.C. - I d.C.): a longa tradicão de resistência ibérica
}

\author{
Ricardo da Costa (UFES)
}

Neste artigo é analisada a relação entre a História e a Arqueologia através do estudo dos castros portugueses, fortificações criadas entre o século III a. C. e I d.C. no território lusitano. A obra Geografia, de Estrabão, foi utilizada para confrontar os dados arqueológicos. A hipótese sobre a cerâmica e os núcleos familiares dos castros foi tratada a partir de um estudo de caso: o Castro de Carvalhelhos, em Trás-dos-Montes, uma típica região castrense.

Palavras-chave: Arqueologia - Castros - História de Portugal

The relation between history and archaeology is discoursed in this article by the analysis of the Portuguese "castros", fortresses created between III b.C. and I a.D. in the Portuguese territory. The work Geografia, by Estrabão, was used to confront the archaeological data. The hypothesis about the ceramic and the familiar nucleus of the castros are analyzed since the study of one case: the Carvalhelho's castro, in Trás-os-Montes, a region typically full of castros.

Keywords: Archaeology - Castros - Portugal History 


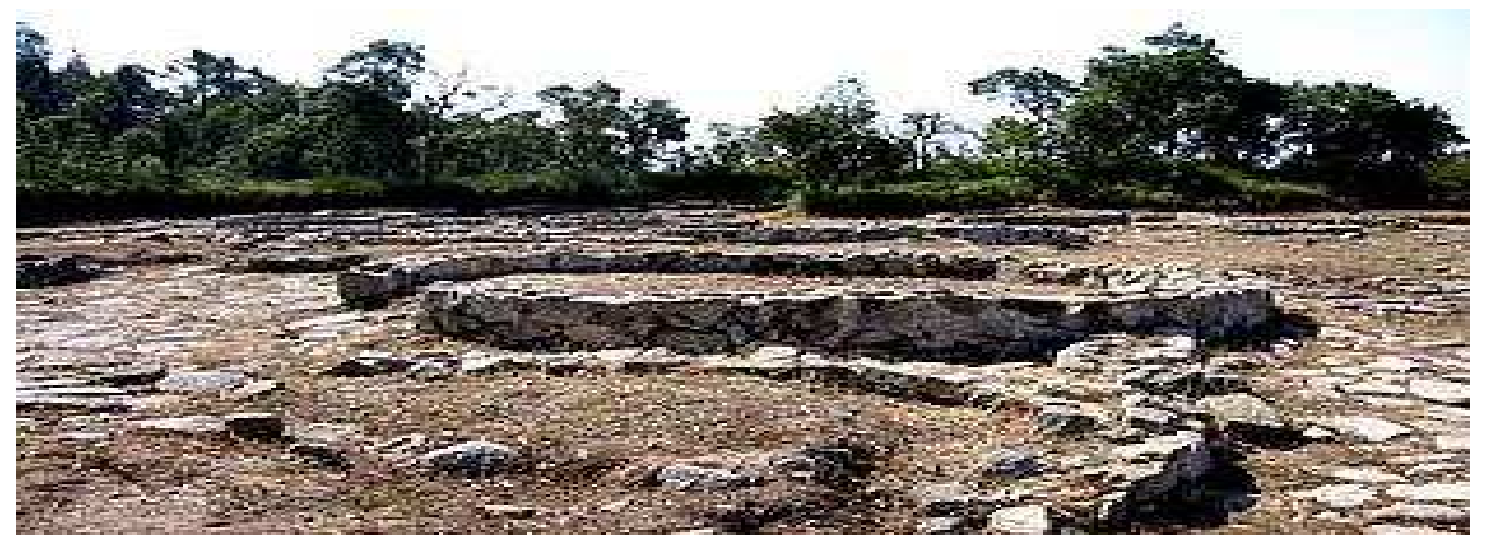

Cultura castreja de Cividade de Terroso (Portugal)

Existe um hiato na arqueologia medieval lusitana para as questões sobre as quais nos propomos debruçar neste ensaio, face aos raros trabalhos publicados. Basicamente, os trabalhos sobre Arqueologia medieval portuguesa se encontram publicados em Arqueologia e História (órgão da Associação dos Arqueólogos Portugueses, 10 volumes, Lisboa, 19221932), mas contém essencialmente estudos sobre epigrafia, numismática e história da arte (MARQUES, 1988: 43). Uma importante exceção é o estudo das escavações sobre a batalha de Aljubarrota realizado por PAÇO (Dicionário de História de Portugal, vol. I: 109111).

Mas não exageremos; nossa distância aumenta nosso desconhecimento. Face a esta dificuldade, percorremos um pequeno trajeto em busca de pontos em comum com o universo maior de nossas pesquisas: a guerra e seus componentes (para o caso luso, razias e fossados), nativos ibéricos e "estrangeiros", mecanismos de defesa relativos ao estabelecimento geográfico, utilização do habitat natural, etc.

É aqui que se insere a cultura castreja. De modo genérico, podemos situar os castros portugueses numa longa tradição cultural de resistência "local" (ibérica) ao que é invasor, mas isso já faz parte de nossas conclusões. 
O conhecimento de resistências em forma de mecanismos de defesa militar anteriores ao processo de Reconquista, ajuda a entender a mentalidade bélica em que se insere o "estado de guerra permanente" (conceito utilizado por MATTOSO, s/d: 478, para o período imediatamente anterior à Reconquista clássica, que compreende os séculos VIIIXI) dos séculos subseqüentes. A compreensão e a utilização dos métodos arqueológicos é de importância fundamental, principalmente para a Alta Idade Média, e o caso ibérico ainda tem um vasto campo a ser explorado.

Antes de abordarmos o assunto propriamente dito, é necessário que deixemos claro a nossa posição frente à relação entre História e Arqueologia. Os acalorados debates que surgiram entre historiadores e arqueólogos quanto a uma primazia disciplinar estão hoje totalmente ultrapassados (MOBERG, 1986: 187). O decreto de Lênin criando a Academia de História da Cultura Material da URSS em 1919, assumindo as atribuições da Comissão Arqueológica do regime czarista, veiculou a nova disciplina com o materialismo histórico (PESEZ, 1993: 177). Hoje, a Arqueologia ainda é a melhor via de acesso à história da cultura material, porém isso não restringe seu campo a abordagens meramente materialistas:

(...)...inseridos na paisagem ou preservados nas coleções, os traços do passado, monumentos ou objetos, são pretexto para um trabalho constante do imaginário (...) Objetos e monumentos, através de sua conservação tão aleatória quanto ocasional, questionam e interrogam (SCHNAPP, 1993: 72).

Portanto, a Arqueologia é História, ou melhor, existe um entrelaçamento tão grande que as diferenças podem, grosso modo, ser encontradas nas técnicas utilizadas pelos profissionais de ambas as áreas. Definindo melhor: a Arqueologia responde a perguntas que os documentos escritos não podem nos dar; mas o que são os documentos senão material arqueológico? São eles cultura material (PESEZ, 1993: 181) da mesma forma que tijolos, moedas ou monumentos.

Mais: o documento escrito é também um monumento, na medida em que foi forjado por mãos humanas. Em ambos os casos a interferência cultural se dá através de mecanismos inerentes ao gênero humano; homo sum et, humani nihil a me alienum puto 
("Sou homem: nada do que é humano eu considero estranho a mim". Frase de Terêncio (Terentius) (195-159 a.C.), comediógrafo romano (africano) - BOWDER, s/d: 251-252).

Concluindo, há uma indissolubilidade disciplinar entre História e Arqueologia, notadamente para a História Antiga e Medieval. A similaridade das definições de ambas as disciplinas permite essa asserção:

Arqueologia pode ser definida como o estudo das coisas antigas quando estas pertencem à cultura e à sociedade humanas. Como disciplina, diz respeito tanto a particularidades do passado, em tempos e lugares específicos, como a generalizações sobre acontecimentos passados (WILLEY, 1987: 83).

Além disso, elas possuem uma convergência em seu objeto de estudo: o homem, motivo maior da busca histórica. Nessa perspectiva, as possibilidades do imaginário na Arqueologia a aproximam da História; nossas constantes recriações do passado multiplicam-se numa proporção geométrica, com a abertura de mais uma frente disciplinar interagindo mutuamente no nosso campo, o das Ciências Sociais. Uma "ciência" aberta às possibilidades da imprevisibilidade da ação humana. Os vestígios materiais nada mais são do que isso: a concretude da abstração humana.

\section{Os castros}

Arqueologicamente, um castro (crasto, castelo dos mouros, couto dos mouros, citânia, cêrca, cividades, castelejo, castelares, castelos) (SERRÃO, 1961-1971, vol. II: 532) é um vestígio de uma povoação fortificada, muralhada com uma ou mais fileiras de pedras, um ou mais fossos, e quase sempre no topo de um cabeço (SANTOS JÚNIOR, 1957: 28), monte com cume arredondado e algumas vezes com encosta íngreme, geograficamente adequado para o domínio da paisagem local e uma observação à distância.

Os castros eram núcleos populacionais concentrados, forçados a um isolamento defensivo (SERRÃO, 1961-1971, vol. II: 532). Este é o habitat castrejo típico. Seus principais povoados estavam instalados em colinas de substrato granítico, e as populações castrejas utilizaram amplamente este material, principalmente para a construção das 
muralhas, feitas de blocos de granito toscamente recortados. É o que Fabião designa por "civilização do granito", embora o autor afirme que esta caracterização seja mais nítida em sua fase final (FABIÃO, s/d: 192).

Nesta cultura castreja, as casas possuíam planta circular, com cerca de 5 metros de diâmetro. Suas paredes eram formadas por pequenas pedras unidas com cascalho, sem qualquer argamassa. Possuía piso de saibro batido; em seu interior, num canto, uma lareira, revestida de argila; ao centro, um buraco para um poste que suportava a estrutura de cobertura, de colmo, material perecível e de formato cônico (FABIÃO, s/d: 193; SARAIVA, 1991: 20-23). Na parte da frente um átrio, algumas vezes com um forno ou forja.

A cultura castreja localizava-se essencialmente nos distritos de Minho e Trás-osMontes, ao norte do rio Douro. Para o período que compreende o auge da cultura castreja, esta região era constituída por duas zonas culturais distintas: litoral (que chamaremos zona 1) e interior (zona 2) (FABIÃO, s/d: 190). O conhecimento destas zonas é desigual; ao litoral, com mais de 100 anos de escavações contínuas, opõe-se o interior, quase que totalmente desconhecido. Optamos pela zona 1.

Na região do Minho o clima é úmido, com chuvas freqüentes (até $3.000 \mathrm{~mm}$ anuais). Sua geografia é entalhada por uma série de vales paralelos, com falésias delimitando as praias estreitas. O solo, naturalmente pobre, tem sua fertilidade assegurada pela adubação de algas marinhas (Geografia Ilustrada - Europa, 1972: 16-17).

Trás-os-Montes ocupa uma área montanhosa, região de forte erosão secular, com uma topografia movimentada e de vales profundos como os de Tua, Tâmega e Sabor. Seus rios correm por escarpas com altitudes superiores a 1.200 metros. Tal relevo, que assistiu ao surgimento da cultura castreja em território lusitano, explica em parte seu isolamento em pequenos núcleos populacionais. 
Para a zona 1, os castros mais famosos são os de Cividade do Terroso, em Póvoa do Varzim e Viana do Castelo, este último com a escavação de uma pequena necrópole no interior de um núcleo familiar. Existe um desconhecimento sobre as necrópoles do período. O Dr. Carlos Fabião supõe que os ritos funerários castrejos envolvessem a cremação, devido aos numerosos elementos que remetem ao mundo indo-europeu. As escavações arqueológicas mostram

(...).fossas abertas no solo das habitações, forradas com pedras, no interior das quais se guardavam urnas contendo as cinzas do(s) defunto(s). Embora não seja possível atribuir uma datação precisa a estas fossas funerárias, é admissível que correspondam ao período de que tratamos (FABIÃO, s/d: 196).

Com os atuais dados arqueológicos até o momento, face a inexistência de necrópoles espacialmente delimitadas, podemos especular que a maior parte do ritual funerário castrejo se dava no interior do espaço doméstico, provavelmente com o intuito de sacralizar a presença do antepassado, fortalecendo o núcleo familiar celular, base da sociedade castreja. "...o núcleo familiar parece emergir vigorosamente como célula-base da sociedade" (FABIÃO, s/d: 197). A permanência das cinzas enterradas em vasos na casa pode nos sugerir a sacralização do espaço cotidiano, dessa forma "protegido" magicamente contra as habituais invasões a que os castrejos estavam submetidos.

Existem divergências quanto à datação precisa do período que abrange a cultura castreja no noroeste da Península. Seu apogeu situa-se na II Idade do Ferro (post-halstático) entre os séculos III a.C. e I d.C. (SANTOS JÚNIOR, 1957: 29). A criação dos castros propriamente ditos deve corresponder aos movimentos migratórios da área indo-européia da meseta e das regiões meridionais, principalmente com as expedições de túrdulos e turdetanos, descendentes dos antigos tartéssicos, entre os séculos V e IV a. C.:

Parece-nos que não é de excluir a hipótese de essa antiga divisão corresponder à remota divisão social registrada pelo mito fundador de Habis. Assim, os primeiros (túrdulos) poderiam pertencer à antiga plebe e os segundos (turdetanos) à velha aristocracia, ou vice-versa (FABIÃO, s/d: 168). 
Estas expedições teriam ocasionado uma instabilidade social em todo o território do Entre Douro e Minho, possibilitando o surgimento destas fortificações.

A cultura castreja sofreu influências externas distintas, a saber:

1) zonas meridionais ibero-púnicas (iniciada no Bronze Final);

2) migração dos túrdulos (refletidas nas técnicas, nos motivos cerâmicos e na ourivesaria);

3) influências continentais (com o crescente deslocamento das comunidades indoeuropéias) (FABIÃO, s/d: 192).

É difícil estabelecer com precisão a intensidade com que cada cultura externa influiu sobre a cultura castreja. De qualquer modo, foi essa cultura miscigenada que existia quando os romanos chegaram. A partir da conquista romana (que teve início em 205 a. C.) se deu progressivamente a romanização da cultura castreja, com a redistribuição e planificação urbanística dos castros sob a égide do invasor.

A ocupação cartaginesa no sul da Península (a partir de 237 a. C., com a invasão de Amílcar Barca - Hamilcar Barcha, m. 229-228 a.C.) e a II Guerra Púnica (218-201 a. C.), principalmente com as batalhas de Sagunto (219, início da guerra, com a vitória de Aníbal [Anibal ou Hannibal, 247-183 a.C.] no cerco à cidade), Becula (208) e Ilipa (207) (vitórias de Cipião Africano [Scipio Africanus, cônsul, 205 e 194 a.C.], com a conquista da Espanha para Roma) não influíram diretamente na cultura castreja de Entre Douro e Minho, mais ao norte da Península. Até 197 a.C., a dominação romana na Península se estendia numa faixa a oeste que ia de Emporion (no nordeste) a Gades (no sul). A conquista só terminou em 19 a.C., quando Agripa (Agrippa, m. 12 a.C.) dominou os últimos focos independentes asturianos. Será a partir de então que se dará a referida romanização da cultura castreja.

Um ótimo exemplo da influência romana é a escavação de Citânia de Safins, em Paços de Ferreira. Ela mostra um extenso povoado castrejo, com duas redes de muralhas à direita e uma divisão interna muralhada. A parte inferior da citânia mostra os típicos núcleos habitacionais circulares castrejos, reordenados em "bairros", em substituição ao 
"caos" anterior pré-romano. Na parte inferior, observamos quase 40 núcleos familiares circulares, e aproximadamente 15 núcleos quadrados. Estes últimos possivelmente foram construídos após a reordenação espacial romana, já que não fazem parte do habitat castrejo anterior (numa posição divergente, José Hermano Saraiva relaciona as casas de formato retangular à invasão céltica, e sua subseqüente miscigenação. SARAIVA, 1991: 21).

Figura

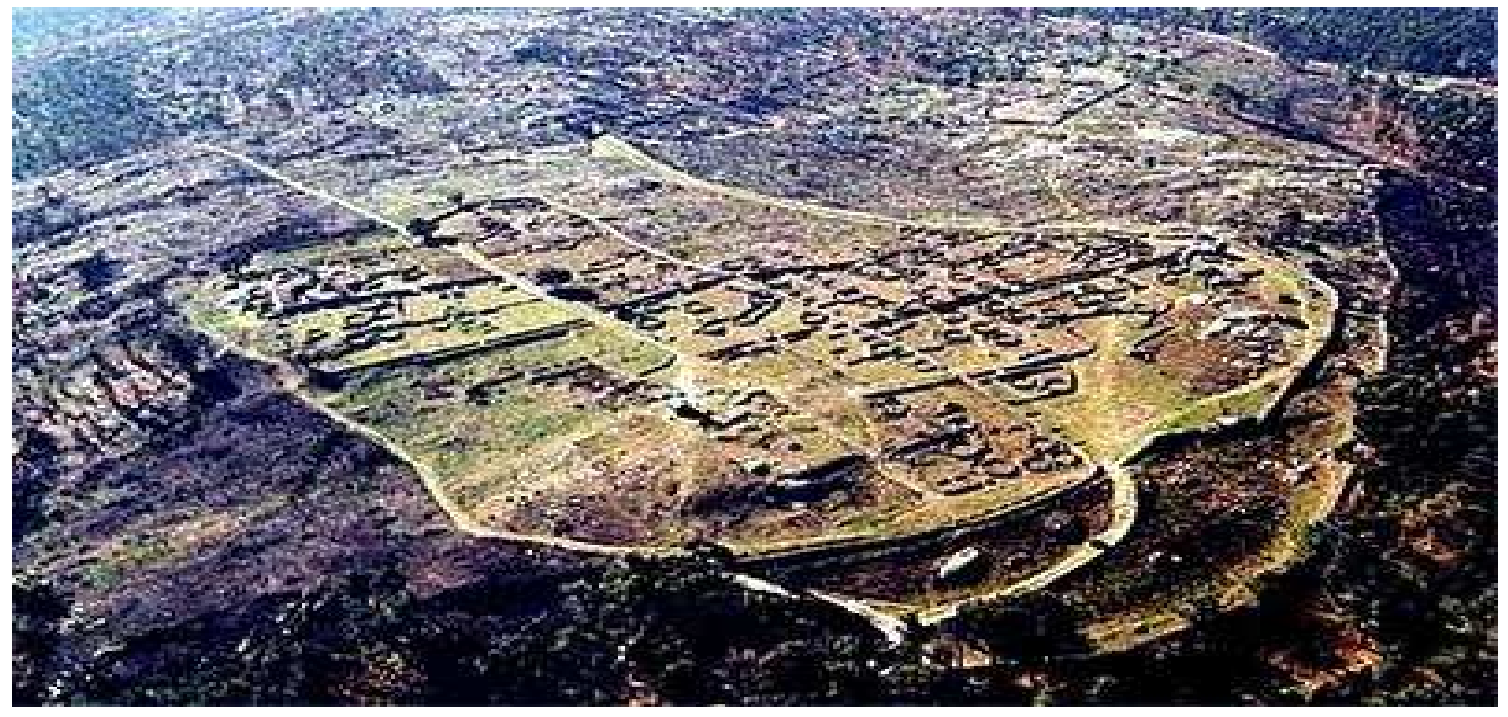

Vista aérea do oppidum de Safins (Internet).

É importante ressaltar que, pelos dados fornecidos pelas escavações, cada casa castreja deveria reunir várias células familiares, ou uma família ampla, de 20 a 50 pessoas, constituindo uma "unidade suprafamiliar mais vasta" (FABIÃO, s/d: 197). Para o tema proposto, dispomos de mais informações de "índole arqueológica" (FABIÃO, s/d: 191) do que documental. No entanto, o geógrafo grego Estrabão (c. 64 a. C.- 25 d. C.), nos oferece um rico panorama dos povos peninsulares quando da conquista romana ("Strabo, nascido em Amasia, no Ponto [...] estudou em Roma por volta de 44-35 a. C. [...] Escreveu Memorandos sobre a História (Estudos Históricos), em 47 livros [...] deixou também 17 livros preservados sobre geografia" - BOWDER, s/d: 145).

Estrabão é um autor que deve ser utilizado com uma certa dose de prudência, principalmente quanto às suas apreciações de teor etnográfico. Sua obra reflete a visão do 
conquistador, com todo o seu desprezo pelas culturas bárbaras; a conquista romana é um imenso "esforço civilizador" (FABIÃO, s/d: 194) sobre as comunidades peninsulares.

Sua posição pró-romana já pode ser vista quando tenta explicar as origens da I Guerra Púnica (264 - 241 a. C.); Estrabão afirma que era prática usual dos cartagineses afogar qualquer marinheiro intruso, encontrado entre a Sardenha e Gibraltar. Pirataria que, mais tarde, "explicaria" moralmente a luta contra os púnicos (STRABO, Geography, XVII, 1, 19). Essa guerra ideológica seria imortalizada mais tarde com a frase de Catão, o Velho (Cato, 234 - 149 a. C.): Ceterum censeo delendam esse Carthaginem (E também penso que Cartago deve ser destruída).

Para ressaltar a importância da "chegada da civilização", Estrabão realça o barbarismo destes iberos pré-romanos, afirmando que muitos viviam em cavernas e choupanas, dormindo no chão e lavando os dentes com urina choca (STRABO, III, 4, 16). Podemos observar a distribuição dos povos que habitavam a Hispania pré-romana, de acordo com descrição de historiadores e geógrafos gregos e romanos (Atlas Histórico edição especial para Encyclopedia Britannica do Brasil Publicações Ltda, MCMLXXXVI: 23). Mas não nos iludamos: esta é uma classificação étnica simples e que apresenta vários problemas. Estrabão e Plínio, o Velho (23/24-79 d. C.), por exemplo, muitas vezes tecem considerações genéricas sobre povos distintos ("...Plínio conseguiu achar tempo, nos intervalos de sua ativa carreira política, para escrever em escala prodigiosa: obras sobre tática de cavalaria [...] sobre a história das guerras contra a Germânia (20 livros), gramática, retórica, história contemporânea (31 volumes), todos perdidos. O que não aconteceu com a História Natural [37 volumes]" - BOWDER, s/d: 210).

A região que nos propomos discutir, a norte do rio Douro, zona 1, era o território de um grupo de etnias designadas genericamente pelo nome de calaicos (FABIÃO, s/d: 191) palavra relacionada com kelticoi, nome que os Romanos davam aos Celtas e que veio a dar o termo galegos SARAIVA, 1991: 22).

Nesta área litorânea castreja, já encontramos divergências entre Plínio, o Velho e Estrabão: o primeiro dá os nomes dos povos que ali viviam (bibalos, celernos, calaicos, 
equesos, límicos, querquenos, além de outros); o segundo afirma que os habitantes do norte do rio Douro eram lusitanos, e que somente após a conquista romana passaram a se chamar calaicos (FABIÃO, s/d: 191). Para um melhor entendimento, sempre que nos referirmos aos calaicos como o povo pertencente à cultura castreja, estaremos também nos referindo a outras etnias da mesma região e que desenvolveram uma cultura semelhante e o mesmo modo de habitação.

Os núcleos suprafamiliares castrejos possuíam provavelmente chefes, vitalícios ou nomeados provisoriamente. Na Citânia de Briteiros, em Guimarães, as escavações arqueológicas encontraram uma grande construção circular (11 m de diâmetro), com bancos corridos em volta, implantada num local mais afastado das habitações familiares (FABIÃO, s/d: 191). Já foram levantadas as seguintes hipóteses para a utilidade de tal monumento:

1) Um conselho de anciãos (sem se saber, no entanto, se existiam antes da conquista romana ou se foi uma implantação criada pelo poder estrangeiro);

2) Alguma instituição colegial ligada à administração de cada povoado e

3) Simplesmente reuniões de familiares, embora de maiores dimensões.

O Dr. Fabião afirma existir as mesmas dúvidas quanto ao título de princeps, que surgiu na época romana e parece designar uma função de chefia (FABIÃO, s/d: 191). Com a conquista romana, os povoados castrejos receberam a designação de castellum (com a abreviatura epigráfica da letra $\mathrm{C}$ invertida). A partir de então o habitante do castro desceu do cabeço e, num processo abrupto, se converteu num agricultor dominado, além de trabalhar para o Império Romano nas construções públicas (pavimentações, fortificações, vias, pontes, etc. - uma das mais perfeitas pontes romanas construídas no atual território português é a de Alcântara [a Norba Cesarina do período romano], com arcos de 100 pés de altura e 180 de largura). Como descreve Serrão:

(...) após o assassínio do caudilho Viriato e a repressão brutal e sangrenta exercida pelas tropas de Júlio Bruto, irrompendo até a Galiza, o habitante dos castros, simultâneamente pastor e guerreiro, bisonho e bravio, foi, por fim, obrigado pela força das armas a descer à planície aberta e a submeter-se à disciplina e à lei do 
invasor, tendo de depor o escudo e a espada curta... (SERRÃO, 1961-1971, vol. II: 535)

Viriato foi um chefe militar lusitano que infligiu sucessivas derrotas aos comandantes romanos, de 147 a 139 a.C. Os romanos firmaram um tratado com ele em 140 a.C. mas o repudiaram posteriomente, e Viriato foi assassinado em 138. Com sua morte, a resistência lusitana entrou em colapso." (BOWDER, s/d: 274).

Mesmo Estrabão, com todo seu discurso pró-romano, descreve a dura resistência que as populações castrejas ofereceram ao disciplinado exército romano. O geógrafo grego diz que as mulheres matavam os filhos para que não caíssem nas mãos romanas, e os prisioneiros morriam pregados na cruz cantando seus cantos de guerra (STRABO, IV, 16$18)$.

Mas deixemos a conquista romana de lado e voltemos a nos ocupar com a organização social castreja. Apesar das discussões referentes à existência de um conselho de anciãos ou alguma instituição colegial, não há dúvidas quanto à autonomia de cada povoado em relação aos outros. Os calaicos não possuíam nenhum tipo de instituição superior para sancionar atos ou leis de cada povoado. Um verdadeira fragmentação de poder, bem caracterizada nos votos religiosos encontrados, quando os calaicos identificavam sua origem "pelo nome do povoado que tinham nascido" ("ao contrário do que sucedia em outras regiões da área indo-européia peninsular" - FABIÃO, s/d: 1981).

Estrabão nos fala de festas familiares que os calaicos faziam em certas noites de lua cheia (STRABO, III, 4-6), provavelmente associadas a ritos religiosos. Conhecemos uma divindade, de nome Larouco, particularmente venerada na região de Vilar de Perdizes, em Vila Real. É também conhecida a rápida propagação do culto a Júpiter, e a associação sincrética do deus Marte a algumas divindades locais. A inexistência de santuários sugere um culto ao ar livre (FABIÃO, s/d: 198). Mas todas as construções específicas para um culto religioso foram construídas após a ocupação romana, o que não significa necessariamente que não possuíssem algum tipo de sacerdote, ou grupo sacerdotal. 
Baseamo-nos ainda em Estrabão (a partir de agora citado por FABIÃO, s/d: 194-196). Este nos conta que as populações castrejas comiam pão de bolota durante a maior parte do ano. Suas atividades dominantes eram o pastoreio e a recoleção. As mulheres trabalhavam nos campos, os homens apascentavam o gado. Os calaicos ainda se envolviam em incursões de pilhagem nos territórios vizinhos. Tinham pouco vinho, o utilizando em festividades para fins de sociabilidade,

(...)produziam, no entanto, uma bebida fermentada, à base de frutos. Desconheciam o azeite e usavam a manteiga como gordura alimentar e, provavelmente, para outros fins. Não é de excluir, também, a utilização do linho como oleaginosa alimentar" (citado por FABIÃO, s/d: 194-196).

Em contrapartida, a realidade descoberta pela arqueologia é bastante diferente. Aqui nos deparamos com uma situação em que há divergência entre o documento escrito e o material arqueológico. Com qual das duas opções o historiador deve optar?

Pensando de maneira coerente, o documento material não mente, é a prova cabal; o historiador da Antigüidade era movido pelos mesmos motivos ideológicos (visão de mundo, ambição, interesses políticos, etc.) de um historiador do século VI ou XIX. Afinal, somos todos humanos. O desejo de supervalorizar o "ímpeto civilizador" de Roma levou Estrabão a "ver" com olhos excessivamente pejorativos a cultura calaica castreja.

(...).recorde-se que o texto foi escrito enquanto decorriam as últimas campanhas de conquista dos povos Cântabros e Ástures - por isso (Estrabão) sublinha constantemente os caracteres que nelas considera mais "bárbaros" (FABIÃO, s/d: 194-196). O norte peninsular é também, segundo José Mattoso, o local de origem do regime senhorial português medieval” (MATTOSO, 1985: 81-91).

Mas o que nos diz a Arqueologia? Investigações paleobotânicas feitas na Galiza (FABIÃO, s/d: 194) levam a crer que a agricultura de cereais e hortícolas continuava a ter um peso significativo na vida calaica. $\mathrm{O}$ que freou o desenvolvimento da agricultura foi provavelmente a constante instabilidade social castreja, com os hábitos de saques e pilhagens. Mesmo assim, este período em questão viu surgir as primeiras mós manuais giratórias (FABIÃO, s/d: 195). 
Segundo Estrabão, os calaicos utilizavam também o comércio marítimo: ele fala de "barcos revestidos de couro e com estrutura de madeira utilizados pelos povos setentrionais" (FABIÃO, s/d: 195). A arqueologia escavou jóias de ouro fabricadas localmente. Os recursos minerais (ouro e estanho) estimularam o interesse romano pela região (Roma já conhecia a riqueza mineral peninsular desde a dominação cartaginense no sudeste, principalmente entre a I e a II Guerras Púnicas. Com a vitória, os minérios hispânicos [ouro, prata, cobre, estanho, ferro, chumbo] passaram a enriquecer Roma, depois de haver enriquecido Tiro e Cartago).

A cerâmica pode se prestar a equívocos; foram encontrados vasos gregos (ânforas e outras de influência púnica) em vários castros (um deles Cividade do Terroso, em Póvoa do Varzim. Existe um desconhecimento quanto ao conteúdo destes vasos importados; talvez vinho ou azeite.

Quanto à cerâmica local, registra-se recipientes sinuosos, feitos geralmente com pastas grosseiras e com motivos geométricos feitos com incisão ou com matrizes de desenhos variados. Encontraram-se também os primeiro vasos com o auxílio do "torno lento" (fabricação manual) relacionada com o moinho manual giratório, uma aquisição tecnológica do período (FABIÃO, s/d: 196).

Estrabão se refere à utilização da madeira como uma forma de artesanato (STRABO, III, 3, 7). Aqui a arqueologia confirma a fonte documental: no castro de Santo Estêvão da Rocha, em Ponte de Lima, recolheram-se alguns fragmentos destes recipientes de madeira, apenas por circunstâncias excepcionais, pois a madeira é de difícil conservação num sítio, ao contrário da cerâmica ou qualquer tipo de metal. 
Figura 3

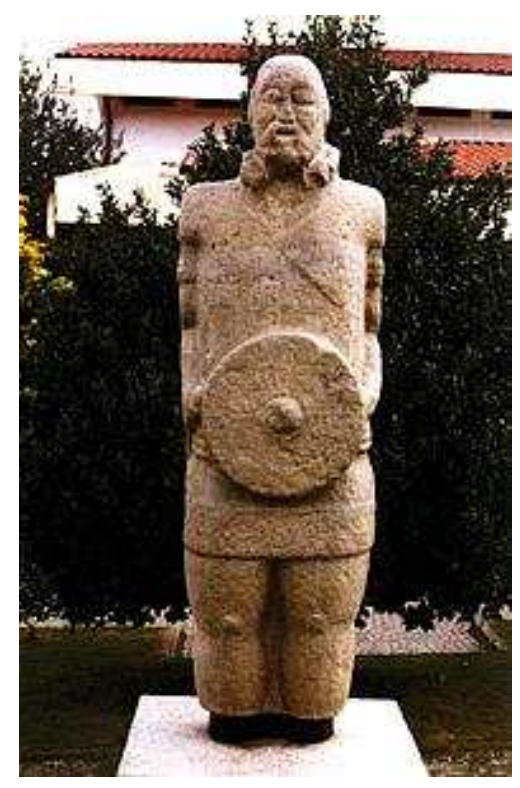

Guerreiro calaico de Boticas

"O Guerreiro consiste num monólito antropomórfico esculpido, erecto e em posição de parada. Apresenta-se vestido com "sagum" (saio exuberantemente decorado com motivos geométricos de círculos concêntricos encadeados e axadrezados), com decote em $\mathrm{V}$ e manga curta, cingido por um cinturão com quatro nervuras paralelas. A cabeça é proporcionada, exibindo um cabelo curto e deixando livres as orelhas, barba e bigode. Austenta as seguintes armas: "caetra" redonda e plana (típico escudo redondo), com umbo, com decorações do tipo "labirinto", que segura na mão esquerda com correias cruzadas no antebraço, e na mão direita empunha um punhal triangular curto, com pomo discoidal, introduzido numa bainha com o conto de perfil circular e linhas transversais de possíveis travessas. Usa no pescoço um torque (peça de ourivesaria típica nos guerreiros da época), com aro aberto e em cada braço, uma "víria" de três toros (espécie de pulseira). O Guerreiro Calaico ou Castrejo é o expoente máximo da Arqueologia Nacional e representa, segundo os autores mais avalizados nesta matéria, a imagem da Divindade e o caracter guerreiro das civilizações castrejas que habitaram a nossa região." Internet.

$\mathrm{Na}$ metalurgia, os calaicos demonstraram grande especialização, principalmente com o bronze e o ouro. Utilizavam uma espada curta, com cabo de bronze (encontrada na 
Citânia de São Julião, em Vila Verde) e facas de lâmina curta, encontradas na Citânia de São Julião, no Castro de Santa Marta das Cortiças (Falperra, em Braga) e no Castro da Baiza (Avintes, em Gaia). Aqui também se confirma Estrabão, que afirma que os lusitanos ainda combatiam com lanças de bronze. Provavelmente só após a conquista romana a civilização do ferro introduziu-se na região. Divergindo do Dr. Carlos Fabião (cuja posição adotamos aqui), José Hermano Saraiva afirma que o ferro foi introduzido na região com a invasão celta, no I milênio a. C. (SARAIVA, 1991: 21).

Carvalhelhos é uma aldeia pertencente à freguesia de Beça, concelho de Boticas. Situa-se a $800 \mathrm{~m}$ de altitude, a $27 \mathrm{~km}$ de Chaves, para Sudoeste (todas as referências da escavação do castro de Carvalhelhos contidas aqui são de SANTOS JÚNIOR, 1957). Portanto, no distrito de Trás-os-Montes, região tipicamente castreja, como vimos anteriormente.

O castro foi "descoberto" pelo Sr. J. R. dos Santos Júnior em 1950, quando estava descendo a pé o caminho que vem de Lavradas para Carvalhelhos. Visível a olho nu, a muralha castreja estava quase toda derrubada (suas pedras foram utilizadas pela população local para a construção de casas), com seus fossos defensivos ainda evidentes. O Sr. Júnior constatou a existência de um ouriçado de pedras espetadas na terra, constituindo-se em mais uma linha de defesa (ao que parece, o reforço de pedras fincadas não é uma característica comum a todos os castros portugueses. Sua utilização parece demonstrar, além de uma maior preocupação defensiva, um desenvolvimento da arquitetura militar castreja). Isso dava ao castro de Carvalhelhos um interesse maior do ponto de vista arqueológico.

Nos anos seguintes (até 1957, data da publicação do trabalho aqui pesquisado) foram realizadas ao todo cinco escavações arqueológicas (1951, 1952, 1953, 1956 e 1957). Para não nos determos exaustivamente em cada uma delas, faremos um breve comentário acerca dos achados materiais no castro de Carvalhelhos. São os seguintes: 
1) Fragmentos de cerâmica, basicamente 03 tipos: a\} pouco espesso e de tonalidade escura (o mais abundante); b pouco espesso e de tom claro, e c $\}$ textura granosa, face interna clara e externa escura;

2) Minério de ferro (03 pedaços) e um cristal de perite de ferro do tamanho da cabeça de um dedo;

3) Duas moedas: um vintém de D. Luís (encontrada na muralha) e outro vintém de D. Carlos (na casa retangular, que falaremos adiante).

O castro de Carvalhelhos é conhecido na região como crasto, ou couto dos mouros. Antes de seu tombamento - em Portugal, a classificação jurídica para patrimônios históricos chama-se "imóvel de interesse público". O castro de Carvalhelhos está enquadrado no decreto no. 38.941, de 06 de novembro de 1951 - o castro sofreu uma série de assaltos realizados pelas populações locais com o intuito de utilizar as pedras para construção de casas. Mesmo após o tombamento, o castro sofreu um assalto: "...um habitante de Carvalhelhos de nome Alexandre Alves se metera a fazer uma casa e que quatro carreiros ao serviço do mesmo, cada um com seu carro de bois, tinha ido ao castro buscar pedras e as tinham arrancado da muralha reconstruída e das casas redondas por nós descobertas..." (SANTOS JÚNIOR, 1957: 38). O indivíduo foi processado pela Fazenda Pública, mas não foi condenado a repor as pedras.

Com subsídios arrecadados por órgãos governamentais, as escavações puderam descobrir uma parte da muralha $(50 \mathrm{~m})$ na zona sul, além de três casas circulares e uma retangular. Numa parte da muralha externa foi encontrada uma "porta", com $88 \mathrm{~cm}$ de largura, e uma segunda "porta" interna (chamada de porta principal), de 1,40 m de largura. Foram encontradas ainda vestígios de três muralhas - um habitante da região afirmou que existiam 7 muralhas no castro, antes das depravações. Todas essas "entrevistas" do Sr. J. R. dos Santos Júnior com velhos habitantes do local não serão aqui comentadas. Fazem parte de outro tipo de trabalho, mais ligado ao imaginário e à criação de mitos e lendas relativas ao castro em questão. Outra "porta" foi escavada (chamada pelos populares de cavalo dos mouros), do outro lado do riacho que lhe corre no sopé. 
Um aspecto interessante deste castro foi a descoberta de pelo menos dez rampas de acesso à muralha. É um dado que afirma o desenvolvimento arquitetônico do castro. Como no trabalho do Sr. J. R. dos Santos Júnior não foram feitas datações, podemos supor que a construção castreja seja num período mais recente, ou até mesmo que tenha sido novamente utilizado pelas populações do alto medievo. Isso quase que antecipa as conhecidas pontes elevatórias dos castelos medievais. Demograficamente, também pode sugerir um crescimento populacional. São conjecturas possíveis, até termos uma datação mais precisa (como o trabalho aqui pesquisado é de 1957, existe a possibilidade do castro já ter sido datado pelos arqueólogos portugueses, e não ser do nosso conhecimento)

O castro de Carvalhelhos possui uma tríplice linha de fossos, com aberturas que variam de 4 até 12 metros (mas aqui podemos ter a ação da erosão). Com as pedras fincadas comentadas anteriormente (num total de cinco grupos - o maior grupo tem 18 a $20 \mathrm{~m}$ de comprimento por 3 a $4 \mathrm{~m}$ de largura, o menor, $3 \mathrm{~m}$ de comprimento por 2 de largura.), o castro de Carvalhelhos era muito bem defendido, tendo caído possivelmente por prolongado cerco (que trazia consequentemente a fome dos sitiados).

O castro situa-se numa zona granítica com xisto, rocha de textura laminar ou acicular, metamórfica, como a ardósia. A região do castro é rica de minério de estanho e de volvrâmio. Foi encontrado ainda um "esconderijo" (devidamente assaltado), próximo do cavalo dos mouros, que continha 200 kilos de cassiterite (a cassiterite é um valioso minério de estanho que, na Antigüidade, teve uma grande importância para a fabricação de objetos de bronze). Seria demais supor que as populações castrejas, obrigadas a trabalhar sob o jugo de Roma, tenham deliberadamente ocultado o minério para um posterior aproveitamento? É também provável que tenha despertado o interesse romano num cabeço próximo há vestígios de explorações mineiras. Isso também viabiliza a hipótese de queda do castro por cerco - a região de Trás-os-Montes foi uma das últimas a cair quando da conquista romana. *

A continuidade da utilização do espaço social da Antigüidade à Idade Média é colocada por diversos autores, como Mumford, 
A pura e simples necessidade levou ao redescobrimento daquela antiga salvaguarda urbana, a muralha. Contra os ataques súbitos, uma muralha de guarda durante tôdas as horas, era mais útil que qualquer quantidade de coragem militar. A fôrça e a segurança de uma fortaleza empinada numa rocha íngreme podiam ser reproduzidas mesmo nas terras baixas (MUMFORD, 1965: 327)

A necessidade de proteção contra ataques perpetrados por povos estrangeiros, ou mesmo vizinhos, trouxe de volta a cerca, a muralha, para o primeiro plano das preocupações das comunidades medievais. Posteriormente, em Portugal criou-se o "direito senhorial de fossadeira", que exigia dos homens livres (peões), a obrigação de escavar o fosso protetor dos acampamentos e de os defender, em substituição ao serviço militar efetivo (MATTOSO, s/d: 485). Isso para o período que compreende os séculos VIII-XI.

Essa preocupação possivelmente pode ter trazido os antigos castros de volta, quer pelas suas possibilidades de concentração numa área mais alta e, portanto, privilegiada para resistir a um cerco ou razia muçulmana, quer pela simples utilização e reaproveitamento de habitações abandonadas.

Temos vários indícios que apontam para uma reutilização social dos castros. Essa retomada do espaço castrejo já se dá no início da ocupação romana, quando novas áreas, mais baixas em relação ao antigo núcleo defensivo castrejo, começam a ser ocupadas, sob o domínio de Roma.

Em 332, a Espanha sofre uma redivisão política, passando a ter cinco províncias: Bética (capital Hispalis - Sevilha), Tarraconense (capital Tarragona), Lusitânia (capital Emerita Augusta, Mérida), Galiza (capital Astorga ou Bracara, Braga) e a Cartaginense (capital Cartagena). Havia ainda dois anexos: as Baleares (capital Palma) a Mauritânia Tingitana (capital Tingis, Tânger) (LOT, 1985: 251).

O período de paz "quase ininterrupta" foi quebrado em 409 com a chegada de alanos, suevos, vândalos asdingos e vândalos silingos. "Durante dois anos a Espanha foi posta a saque, principalmente a oeste, onde já não restavam quaisquer tropas romanas" (LOT, 1985: 251). 
A luta pelo controle político levou ao extermínio dos vândalos silingos, além de uma série de revoltas sociais camponesas conhecidas como "bagaudas". Esse período de instabilidade social pode ter trazido momentaneamente, para as populações a norte do Douro, os antigos castros de volta, como locais seguros, de refúgios, um abrigo para os constantes ataques entre bárbaros (o tratado assinado com o Império em 411, que acantonou os invasores como federados, não amenizou a luta). Contudo, com a progressiva decadência do Império, a partir dos séculos III-IV, os castros sofrem um abandono generalizado,

(...) ao estabelecimento nos pontos mais elevados do terreno, como lugares de habitação mais defensáveis, mas ásperos e ingratos à vida doméstica, se havia já preferido, com a consolidação da paz romana, a fixação nos vales e nas planuras agricultáveis. A uma norma de vida isolada e agressiva, de guerrilhas e assaltos, com uma economia baseada principalmente no pastoreio, sucedia-se, (...) a adaptação à vida pacífica do camponês, fecundando o húmus viçoso dos latifúndios, ainda virgens do sulco do arado (SERRÃO, 1961-1971, vol. II: 533).

Embora o quadro oferecido por Serrão para os séculos seguintes à decadência do castro seja um tanto pueril, é de se notar a mudança espacial das populações castrejas, agora instaladas em espaços mais férteis para o plantio.

Como se dá então esse reaproveitamento medieval do castro? O mesmo Serrão nos oferece pistas: "Muitos desses núcleos castrejos (...) perduraram no decorrer de sua evolução (...) alguns deles mantiveram-se mesmo durante o domínio visigodo e a Alta Idade Média, dando origem a muitas das povoações actuais" (SERRÃO, 1961-1971, vol. II: $533)$.

Para o domínio suevo e visigótico, o melhor exemplo da necessidade de manutenção das muralhas se encontra na inscrição lapidar de Mérida. Ela comemora a reconstrução de sua ponte e cerca defensiva pelo dux Salla, que cumpria ordens do rei Eurico (rei visigodo, 466 - 484), no ano de 484 (MATTOSO, s/d: 324). Os constantes ataques de vândalos e suevos às cidades do sul da Península justificavam a preocupação visigoda. Além disso, o atrofiamento urbano generalizado na Europa a partir dos séculos III - IV também atingiu a Península. Muitas cidades ofreram esse abalo demográfico: Leão, 
Astorga, Lugo, Cáceres, Conímbriga, Lisboa, Idanha, Mérida, Évora, Mértola, Beja, Ossónoba. Contraditoriamente, a retração demográfica desse período parece corresponder ao abandono do castro. De qualquer modo, o fenômeno de construção (ou reaproveitamento) de muralhas pode ser um indício seguro de atrofiamento urbano, além da óbvia necessidade de defesa.

Tais incursões bárbaras forçaram as cidades a "concentrarem-se num simples recanto da sua antiga extensão": "A cidade do Baixo Império é um posto defensivo de uma superfície insignificante (10 a 20 hectares), que não comporta senão uma população extremamente reduzida, 3.000 ou 6.000 habitantes" (LOT, 1985: 323). Podemos aqui supor um movimento contínuo: a cada ataque, ou invasão, os antigos castros são utilizados, e, após o fim da incursão, as populações descerem o cabeço e voltarem às suas atividades normais.

Como vimos, a nova redivisão geopolítica na Península, com os grupos bárbaros disputando o espaço "abandonado" por Roma, pode suscitar a probabilidade do castro ser utilizado como ponto seguro para concentração de forças, incursões de surpresa ao campo inimigo, etc. Isso levando-se em conta o acidentado terreno ao norte do Douro, propício para o isolamento de diferentes culturas sob um mesmo sistema defensivo.

Essa região possui uma longa tradição de isolamento cultural e defesa contra "estrangeiros". É dela que a resistência se faz mais tenaz: da conquista romana à conquista muçulmana, ela é o último baluarte a cair. Ela é o foco inicial do processo de Reconquista; é dela que vemos surgir o movimento senhorial (para não falarmos de feudalismo peninsular, motivo de tanta controvérsia entre os historiadores) que se alastra para o sul, no rastro de Ourique, Alcácer do Sal e Las Navas de Tolosa. Nas palavras de Mattoso, é uma região de "reservatório de homens", "área de povoamento mais precoce, região onde frequentemente reina a fome montanhesa, grande alimentadora das descidas, das constantes emigrações" (MATTOSO, 1985, vol. I: 31). 
Mas é durante o período muçulmano que possuímos os melhores indícios de ocupação castreja. Aqui utilizamos a onomástica para relacionar a ocupação com longas tradições locais que perpetuam — muitas vezes sem o saber — essa lembrança.

O próprio caso do castro de Carvalhelhos, com seu cavalo dos mouros, não é um bom exemplo disso? A associação entre o antigo nome castro e suas posteriores designações saltam aos olhos: casal dos mouros, cerca dos mouros, feira dos mouros, toural dos mouros, couto dos mouros (SANTOS JÚNIOR, 1957: 28). Todos nomes para castro. Essa permanência da língua nos oferece a possibilidade de fazer tal conjectura. Mas não é só. Para esses séculos que se seguem, a "coincidência" onomástica não é menor. A partir do século IX, com as invasões normandas, todo o Ocidente medieval cobre-se de fortalezas. Os textos medievais dão os mais variados nomes: castellum, castrum, burgus, urbs (PIRENNE, 1962: 60). Pirenne enfatiza a associação burgo-instituição militar desde a sua origem. É para se ressaltar:

Tais como nos surgem, os burgos são antes de tudo instituições militares. Mas a este caráter primitivo cedo se juntou o de centros de administração. $\mathrm{O}$ castelão deixou de ser simplesmente o comandante dos cavaleiros da guarnição castrense. $\mathrm{O}$ príncipe delega-lhe a autoridade financeira e judiciária (...) Em caso de guerra, os seus habitantes encontravam ali um refúgio (...) É uma população de fortaleza (PIRENNE, 1962: 62-63).

As coincidências onomásticas permanecem, mesmo tratando-se de áreas distintas, separadas pelos Pireneus.

Dessa forma, não é de se estranhar que exista a possibilidade do uso do castro até para a construção de uma fortaleza, utilizando-se sua posição privilegiada, além do material granítico, já trabalhado em forma de bloco. Assim, podemos colocar a questão da longa permanência do castro como local de resistência, enraizado em sua geografia. Sem nos levarmos pelas antigas posturas nacionalistas ("Nos castros implantam-se velhas raízes da nacionalidade portuguesa. E assim, estudar os castros e a cultura castreja é fazer nacionalismo e do mais são" - SANTOS JÚNIOR, 1957: 29), o estudo do castro é o estudo de uma longa tradição de isolamento, de resistência cultural ibérica, onde os povos lusos (e 
aqui englobo o universo tribal peninsular) sempre se oporam ao que veio de fora, ao "outro".

Por fim, como também é um dos objetivos deste ensaio, devemos enfatizar a importância de uma maior interdisciplinaridade entre a Arqueologia e História, assunto já comentado aqui, mas nunca insuficiente. Nossa posição, de uma proximidade quase tênue, deve, sempre que possível, ser trabalhada futuramente em posteriores trabalhos acadêmicos. Como afirma Kern,

(...) reafirmamos que a permanência de uma postura que teima em opor História e Arqueologia, tornou-se obsoleta e no mínimo vítima de um maniqueísmo simplista, que em nada colabora para a construção de um conhecimento mais objetivo da vida e da dinâmica social do Mundo Antigo (KERN e DIAS, 1990: 128).

O que eu acrescento: do Mundo Medieval também.

Bibliografia

Arqueologia e História (Associação dos Arqueólogos Portugueses), 10 volumes, Lisboa, 1922-1932.

Atlas Histórico - edição especial para Encyclopedia Britannica do Brasil Publicações Ltda. Barcelona: Editorial Marin, S.A., MCMLXXXVI.

BOWDER, Diana. Quem foi quem na Roma Antiga. São Paulo: Art Editora, s/d.

BOWDER, Diana. Quem foi quem na Grécia Antiga. São Paulo: Art Editora, s/d.

FABIÃO, Carlos. "O passado proto-histórico e romano - A II Idade do Ferro". In: MATTOSO, José (org.). História de Portugal - Antes de Portugal. Lisboa: Editorial Estampa, s/d.

Geografia Ilustrada - Europa. São Paulo: Abril Cultural, 1972.

KERN, Arno Alvarez e DIAS, Adriana Schmid. "A propósito das relações entre Arqueologia e História no estudo das sociedades antigas". In: Anais do IV Simpósio de História Antiga e I Ciclo Internacional de História Antiga Oriental. Porto Alegre: Universidade Federal do Rio Grande do Sul (IFCH)/Dep. de História - FAPERGS, 1990. 
LOT, Ferdinand. O fim do mundo antigo e o princípio da Idade Média. Lisboa: Edições 70, 1985.

MARQUES, A. H. de Oliveira. Guia do Estudante de História Medieval Portuguesa. Lisboa: Editorial Estampa, 1988.

MATTOSO, José (org.). História de Portugal - antes de Portugal. Lisboa: Editorial Estampa, s/d.

MATTOSO, José. Identificação de um País - ensaio sobre as origens de Portugal (10961325). Lisboa: Editorial Estampa, 1985.

MOBERG, Carl-Axel. Introdução à Arqueologia. Lisboa: Edições 70, 1986.

MUMFORD, Lewis. A cidade na História - suas origens, suas transformações, suas perspectivas. Belo Horizonte: Editôra Itatiaia Limitada, 1965.

PESEZ, Jean-Marie. "História da cultura material". In: LE GOFF, Jacques (org.). A História Nova. São Paulo: Martins Fontes, 1993.

PIRENNE, Henri. As cidades da Idade Média - ensaio de história econômica e social. Lisboa: Publicações Europa-América, 1962, p. 60.

SANTOS Júnior, J. R. dos. O castro de Carvalhelhos. Porto: Instituto de Antropologia da Universidade do Porto, Imprensa Portuguesa, 1957.

SARAIVA, José Hermano. História concisa de Portugal. Lisboa: Edições Europa-América, 1991.

SCHNAPP, Alain. "Arqueologia". In: BURGUIÈRE, André. Dicionário das Ciências Sociais. Rio de Janeiro: Imago Editora, 1993.

SERRÃO, Joel. Dicionário de História de Portugal e do Brasil. Lisboa: Iniciativas Editoriais, 1961-1971, vol. II.

WILLEY, Gordon R.. "Arqueologia". In: Dicionário de Ciências Sociais. Rio de Janeiro: Fundação Getúlio Vargas, 1987. 